Demiryolu Mühendisliği

Temmuz 2021

Sayı:14, Sayfa: 202-216

Araştırma Makalesi
Railway Engineering

July 2021

Issue:14, Page: 202-216

Research Article

doi: 10.47072/demiryolu.935335

http://dergipark.org.tr/demiryolu

e-ISSN: 2687-2463, ISSN: 2149-1607

\title{
Ayrılmış Demiryolu Hatlarında Mekik Trenler İçin Mikro-Simülasyon Tabanlı Taşımacılık Kapasitesi Analizi
}

\author{
Mehmet Sinan YILDIRIM ${ }^{* 1}$, Ümit GÖKKUŞ ${ }^{1}$, Mustafa KARAŞAHIN²® \\ ${ }^{1}$ Manisa Celal Bayar Üniversitesi, Mühendislik Fakültesi, İnşaat Mühendisliği Bölümü, Manisa, Türkiye \\ ${ }^{2}$ İstanbul Gelişim Üniversitesi, Mühendislik Fakültesi, İnşaat Mühendisliği Bölümü, İstanbul, Türkiye \\ *msyildirim35@eposta.com
}

(Alınış/Received: 09.05.2021, Kabul/Accepted: 23.06.2021, Yayımlama/Published: 31.07.2021)

Öz: Son yıllarda dünyada ticaret hacminin artması ile birlikte, lojistik köyler ve kuru limanlar ile limanlardaki yük akışının düzenlenmesi ve sıkışıklığın azaltılması gibi faydalar sağlanmıştır. Bu tesislerin faydalarından bütüncül bir şekilde yararlanmak için liman ve tesisler arasında düzenli bir yük akışının sağlanması gerekmekte, bu amaçla demiryolu yük taşımacılığının kullanımı son yıllarda gittikçe artmaktadır. Bu çalışmada yük aktarma tesisleri arasında yüksek kapasiteli ve güvenilir bir yük taşımacılığı yapılabilmesi amacıyla, mekik trenlerin taşımacılık kapasitesinin hesaplanması için mikro-simülasyon destekli bir yöntem geliştirilmiş ve örnek bir liman için uygulaması yapılmıştır. Dizel elektrikli ve elektrikli lokomotif kullanım senaryoları, farklı vagon sayıları ve örnek bir güzergah için lokomotif çeker hesapları yapılarak tren hareketlerinin mikro-simülasyon yazılımı kullanılarak modellenmesi ile işletme hızları ve sefer süreleri ortaya konmuştur. Sonrasında kesitlerde hesaplanan sefer süreleri kullanılarak farklı tren sayıları için hat taşımacılık kapasitesi belirlenmiştir. Çalışmada daha yüksek cer kuvvetine sahip olan elektrikli lokomotiflerin kullanımının dizel elektrikli lokomotiflere oranla daha yüksek yük taşımacıllı̆ı kapasitesinin sağlanmasına katkı sağlayabileceği sonucuna varılmış, aynı zamanda mikro-simülasyon yöntemi ve lokomotif çekim hesapları kullanılarak gerçekçi tren sefer süreleri hesaplanmıştır. Çalışmada yapılan kapasite hesabında ise 8 saatlik operasyon süresi boyunca hat kapasitesinin çalıştırılan tren sayısı ile arttığı ve elektrikli lokomotif kullanımında hat kapasitesinin dizel elektrik lokomotife oranla 4 adet lokomotifin işletimi durumunda $\% 6,25$ oranında arttığ görülmüştür.

Anahtar kelimeler: Demiryolu, Kapasite, Mikro-simülasyon, Kuru liman, Mekik tren

\section{Freight Transport Capacity Analysis for Shuttle Freight Trains in Dedicated Railway Lines Using Micro-Simulation}

\begin{abstract}
In recent years with the emergence of the dry port concept, benefits have been achieved such as regulation of cargo flow and reducing congestion in dry ports, freight villages and ports. The use of railway transportation for the establishment of a regular freight flow between ports and dry ports has been increasing in recent years for providing the benefits of dry ports and freight villages holistically. In this study, a micro simulation-assisted method was developed and implemented in a case study to calculate the transportation capacity of the shuttle trains for providing a high capacity freight transportation between these facilities. The freight transport capacity of the railway corridor was presented by demonstrating calculations for locomotive types, wagon numbers and locomotive pulls on a sample line of a typical port. Train movements were modelled with using a microsimulation software. In this study, it has been concluded that the use of electric locomotives with higher traction power may contribute to the establishment of higher freight transport capacity compared to diesel locomotives. At the same time, it has been shown that more realistic travel time and capacity calculations can be made by using micro-simulation method and locomotive pull calculations. The case study indicated for a 8 hours shuttle train operation period, electric locomotive provide \%6.25 more transport capacity compared with the diesel-electric locomotive considering 4 locomotives in operation.
\end{abstract}

Keywords: Railway, Capacity, Micro-simulation, Dry port, Shuttle train

Atıf için/Cite as: M. S. Yıldırım, Ü. Gökkuş, M. Karaşahin, "Ayrılmış demiryolu hatlarında mekik trenler için mikro-simülasyon tabanlı taşımacılık kapasitesi analizi," Demiryolu Mühendisliği, no. 14, pp. 202-216, July. 2021. doi: 10.47072/demiryolu.935335 


\section{Giriş}

Limanlar ile hinterlandları arasındaki yük taşımacılığının güvenilir ve yüksek kapasiteli bir şekilde sağlanması, limanların lojistik ağlarındaki dağıtıcı rolleri ve daha ekonomik bir lojistik ağının sürdürülmesi için önemlidir [1]. Ö̈zellikle kuru limanlar ve lojistik köylerin ortaya çıkışı ile birlikte, demiryolu taşımacılığının önemi her geçen gün artmıştır. Limanlar ve hinterland arasındaki demiryolu yük taşımacılı̆̆ tarifeli tren trafiğinin sekteye uğratılmaması gerekmektedir [2]. $\mathrm{Bu}$ hatlar üzerinde gerçekleştirilen yoğun taşımacılık faaliyetlerinde ise blok veya mekik tren adı verilen ve iki nokta arasında taşımacılığı kesintisiz sürdüren trenler kullanılmaktadır [3]. Özellikle mevcut hatların kapasite artırımı veya yeni hatların planlanması aşamalarında hat taşımacılık kapasitelerinin belirlenmesi önem taşımaktadır [4].

Demiryolu hattının kapasitesi, belirli bir kesitinde belirli bir süre içinde güvenle geçebilecek tren sayısı, taşınabilecek yolcu veya yük olarak belirtilebilir [5]. Kapasite, demiryolu altyapısı, sinyalizasyon sisteminin özellikleri, işletmecilik yaklaşımı ve trenlerin karakteristikleri gibi bir dizi faktörden etkilenmektedir. Kapasiteyi belirleyen en önemli altyapı ve işletmecilik faktörleri ise kurplar ve rampalar nedeniyle hız kısıtlamaları, hat geçişleri ve birleşmeleri, terminaldeki bir treni geri döndürmek için gereken zaman, yük ve yolcu trenlerinin beraber işletilmesidir [6]. Literatürde demiryolu kapasitesinin belirlenmesi için trenlerin hızını ve mesafesini hesaplayan tren direnç ve hareket denklemleri kullanan matematiksel modeller ve özelleşmiş mikrosimülasyon yazılımları kullanılmaktadır. Demiryolu kapasitesinin belirlenmesi için modelleme yaklaşımları Şekil 1'de görülmektedir.

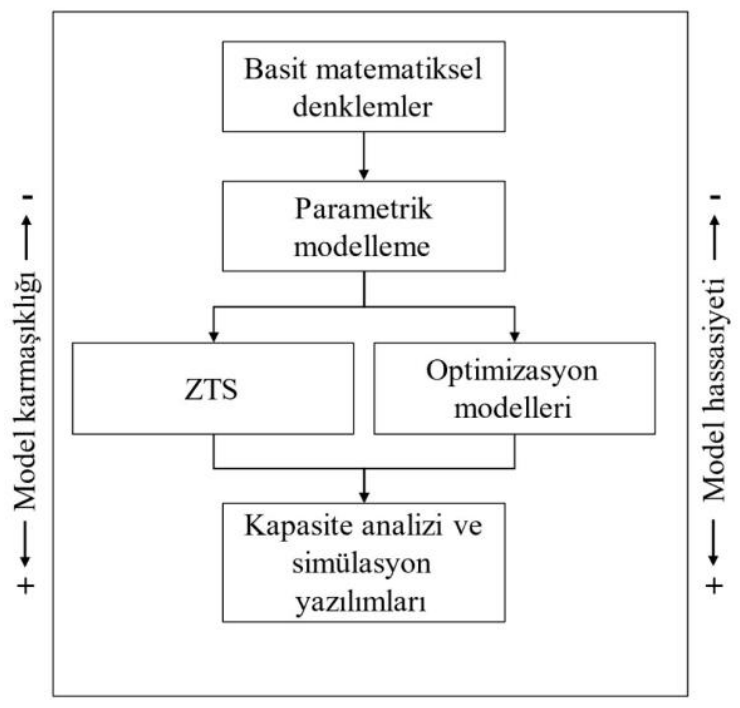

Şekil 1. Demiryolu kapasitesi belirlenmesi için modelleme yaklaşımlar [7]

Demiryolu kapasitesinin belirlenmesinde matematiksel modeller kullanılabileceği gibi daha karmaşık ve hassas olan parametrik modelleme, ve çeşitli detaylarda miko-simülasyon modelleri da kullanılabilir [8]. Özellikle tren zaman çizelgesinin planlanması ve atıl hat kapasitesini belirlenmesinde optimizasyon yöntemleri son yıllarda siklıkla kullanılmaktadır [9-10] . Demiryolu hat kapasitesinin belirlenmesi için kullanılan analitik yöntemlerden biri UIC-406 olarak adlandırılan zaman çizelgesi sıkıştırma (ZÇS) yöntemidir [8], [11]. Son yıllarda demiryolu kapasitesinin hesaplamasında simülasyon yöntemleri de sıklıkla kullanılmaya başlanmıştır. Bunlara etmen tabanlı simülasyon yöntemleri [8-10] ve kesikli olay simülasyon yöntemleri [1113] örnek verilebilir. 
Özellikle kuru liman ve yük aktarma istasyonlarının kullanımı durumunda tren ve vagon sayısı, lokomotif özellikleri, liman ile aktarma istasyonu arasındaki mesafe, mevcut demiryolu trafiğinin özellikleri gibi kriterler demiryolu kapasitesini doğrudan etkilemektedir. Literatürde demiryolu kapasitesinin tayini ve yük trenleri işletmeciliği ile ilgili kısıtlı sayıda çalışma bulunmaktadır. $\mathrm{Mu}$ ve Dessouky [16] optimizasyon tabanlı sefer planlama yöntemi ile yük trenlerinin sefer planlamasını gerçekleştirmiştir. Pouryousef ve Lautala [17] RailSYS simülasyon yazılımı ile demiryollarındaki kapasite kullanımı ile hizmet düzeyi arasındaki ilişkiyi incelemiştir. Meirich ve Nießen [18] bir demiryolu hattında işletilen yük trenlerinin sayısını maksimize etmek için bir sefer optimizasyon modeli önermiştir. Yalçınkaya ve Bayhan [19] stokastik karakter içeren ve demiryolu trafiğindeki düzensizlikleri çözerek uygulanabilir tren çizelgesi oluşturan bir simülasyon modeli geliştirmiştir.

Ülkemizde son yıllarda mevcut hatların elektrifikasyonu sağlanarak, elektrikli lokomotiflerin yük ve yolcu taşımacılığında kullanımı arttırılması hedeflenmektedir. Bu çalışmada ele alınan elektrikli lokomotiflerin, dizel elektrikli veya dizel lokomotiflere olan temel avantajları düşük operasyon ve bakım maliyetleri Elektrik fiyatının mazot ve fosil yakıtlara oranla daha stabil olması, dizel lokomotiflerde bakım maliyetinin fazla olması (kullanılan yağ vb. malzemeler) ile dizel motorlardaki yüksek aşınma, iç sürtünme ve egzoz 1sı kayıplarıdır [20]. Aynı zamanda elektrikli lokomotiflerin daha az gürültü ve hava kirliliğine ürettikleri ve temiz enerji kaynaklarının kullanımını sağladıkları belirtilmiştir. Bununla beraber, elektrikli lokomotiflerin işletilmesi için ilk elektrifikasyon yatırım maliyetleri yüksektir. [21].

$\mathrm{Bu}$ çalışmada literatürde çok az yer alan mekik trenler için ayrılmış hatlardaki veya sadece mekik trenlerin kullanıldığı işletme saatlerindeki kapasite hesabı konusunda değinilmiş ve kapasite hesabı için mikro-simülasyon destekli bir yöntem ortaya konmuştur. Önerilen yöntem örnek bir liman-kuru limana arası demiryolu hattı için uygulanmış ve hat üzerinde tarifeli trenlerin işletilmediği ayrılmış saatlerdeki mekik tren taşımacılık kapasitesi ortaya konmuştur.

\section{Yöntem}

Demiryolu kesitlerinde lokomotiflerin çekebileceği maksimum vagon sayısı veya bu kesitte yapabileceği maksimum hız, lokomotif cer kuvveti, tren fren karakteristiğinde bağlı olarak güvenli duruş mesafesi, kurplar için izin verilen maksimum işletmecilik hızları gibi birçok değişkene bağlıdır. Lokomotiflerin belirli hat koşulları ve yükler altında yapacakları hızlar için tren hareket formülleri kullanılacaktır. Bu formüller trenlerin kurp ve rampalardaki maksimum hızlarının belirlenirken güvenli bir sefer için frenleme mesafelerinin de hesaba katılmasıyla oluşturulmuştur. Hareket halindeki bir trenin belirli bir hızda seyretmesi için yenmesi gereken toplam seyir direnci Denklem 1 ile ifade edilmektedir [22].

$$
R_{S}=\left(r_{L} G_{L}\right)+\left(r_{v} G_{v}\right)
$$

Denklemde $R_{S}$ toplam seyir direnci (daN), $G_{L}$ ve $G_{v}$ lokomotif ve vagon kütleleridir (ton). Denklem 1'de hareket halindeki trene uygulanan lokomotif ortalama direnci $\left(r_{L}\right)$ Denklem 2 ile hesaplanır [22].

$$
r_{L}=0.65 \cdot \frac{13.15}{P}+0.00932 \cdot V+\frac{0.004526 \cdot A \cdot V^{2}}{P \cdot N}(\text { daN } / \text { ton })
$$

Denklemde " $P$ " lokomotif dingil yükü (ton), " $V$ " tren hızı $(\mathrm{km} / \mathrm{h})$, “ $A$ " lokomotif ön görüş alanı $\left(\mathrm{m}^{2}\right)$ ve " $N$ " lokomotif dingil sayısıdır. Vagonların ortalama direnci $\left(r_{v}\right)$ yük vagonları için Strahl formülü kullanılarak Denklem 3 ile hesaplanmaktadır [23]. 


$$
r_{v}=2+0.057 \cdot \frac{V^{2}}{100}(\text { daN/ton })
$$

Trenlerin fren mesafeleri göz önünde bulundurularak kesitlerde yapabilecekleri maksimum hızlar bir dizi denklem aracılığıyla hesaplanır. Fren yüzdesi ile tren durma mesafesi arasındaki ilişki Denklem 4 ile hesaplanmaktadır [24].

$$
\Phi=\frac{3.93 \cdot V^{2} \mp h \cdot S-r_{\text {ort }} \cdot S}{\mu \cdot S} \cdot 100
$$

Denklemde " $\Phi$ " fren yüzdesi $(\%)$, " $h$ " rampa eğim değeri (\%o), " $S$ " fren mesafesi $(m)$, " $r_{\text {ort }}$ " lokomotif ve vagonlar için ortalama direnç ve " $\mu$ " tekerlekler ile sabo arasındaki sürtünme direncidir (daN/ton). " $r$ ort" yük trenleri için Denklem 5 kullanılarak hesaplanır .

$$
r_{\text {ort }}=1.5+\frac{V^{2}}{1500}(\text { daN } / \text { ton })
$$

"S" değeri rampa olması durumunda Denklem 6 ile hesaplanır [24].

$$
S=\frac{V^{2}}{26 \cdot\left(a_{f} \pm a_{r}\right)}
$$

Denklemde " $a_{f}$ " ortalama fren ivmesi $\left(\mathrm{m} / \mathrm{s}^{2}\right)$ ve " $a_{r}$ " rampadan dolay1 etki eden ivmedir $\left(\mathrm{m} / \mathrm{s}^{2}\right)$. Bu değerlerin hesaplanmasında Denklem 6 ve Denklem 7 kullanılır [24].

$$
\begin{gathered}
a_{f}=\frac{\Phi+7}{151} \\
a_{r}=\frac{h(\text { metre })}{100}
\end{gathered}
$$

Denklem 4'deki “ $\mu$ ” değeri farklı hızlar için aşağıda verilen denklemler ile hesaplanır [24].

$$
\begin{aligned}
& \mu_{(20-25)}=\frac{6670+5 \cdot V}{50+V} \quad 20 \mathrm{~km} / \mathrm{h} \leq V<25 \mathrm{~km} / \mathrm{h} \\
& \mu_{(25-30)}=\frac{6670+15 \cdot V}{50+V} \quad 25 \mathrm{~km} / \mathrm{h} \leq V<30 \mathrm{~km} / \mathrm{h} \\
& \mu_{(30-35)}=\frac{6670+20 \cdot V}{50+V} \quad 30 \mathrm{~km} / \mathrm{h} \leq V<35 \mathrm{~km} / \mathrm{h} \\
& \mu_{(35-50)}=\frac{6670+25 \cdot V}{50+V} \quad 35 \mathrm{~km} / \mathrm{h} \leq V<50 \mathrm{~km} / \mathrm{h} \\
& \mu_{(50-95)}=\frac{6670+22 \cdot V}{50+V} \quad 50 \mathrm{~km} / \mathrm{h} \leq V<95 \mathrm{~km} / \mathrm{h} \\
& \mu_{(95-120)}=\frac{6670+25 \cdot V}{50+V} \quad 95 \mathrm{~km} / \mathrm{h} \leq V<120 \mathrm{~km} / \mathrm{h}
\end{aligned}
$$


Çalışmada yük trenleri için kabul edilen karakteristik fren yüzdesi ile demiryolu kesitlerinde azami fren mesafesi için tren hızları hesaplanacaktır. Bu amaçla trenler için fren yüzdesi $(\Phi) \% 40$ ve tren azami fren mesafesi 1000 metre kabul edilmiştir. Hareket halindeki trenlerde birim tona etki eden kurp direnci Denklem 14 ile hesaplanır [25].

$$
r_{k}=\frac{650}{R_{m}-55}(\text { daN/ton })
$$

Denklemde " $R_{m}$ " demiryolu kesitindeki en küçük kurp yarı çapıdır (m). Trene etki eden kurp direnci $\left(R_{k}\right)$ Denklem 15 ve trenin kurp içinde yapabileceği maksimum hız $\left(V_{k}\right)$ Denklem 16 ile hesaplanır [26], [24].

$$
\begin{gathered}
R_{k}=r_{k}\left(G_{L}+G_{V}\right)(d a N) \\
V_{k}=4 \sqrt{R}(\mathrm{~km} / \mathrm{h})
\end{gathered}
$$

Denklemde " $R$ " kurp yarıçapıdır (m). Trenin çekebileceği yük hesaplanırken, cer kuvveti $(\mathrm{P})$ ve " $V$ " için tekerlek kuvveti (T) Denklem 17 ile hesaplanır [24].

$$
T=\frac{360 \cdot P}{V}(d a N)
$$

Tren hareketi esnasında cer kuvveti ile trene etki eden dirençler eşitlenirse, lokomotifin çekebileceği ton cinsinden yük $\left(G_{v}\right)$ Denklem 18 ve Denklem 19 ile hesaplanır [24].

$$
\begin{gathered}
G_{v}=\frac{T-R_{L}-r_{e} G_{1}}{r_{v}+r_{e}}(\text { ton }) \\
r_{e}=r_{r}+r_{k}
\end{gathered}
$$

Denklemde " $r_{r}$ " kesitin rampa değeridir. Kesitlerdeki işletme hızı ayrı ayrı hesaplanan limit hızlarının en küçüğü olarak kabul edilmiştir. Trenin her bir kesitteki işletme hızı $\left(V_{i}\right)$ Denklem 20 ile belirlenecektir.

$$
V_{i}=\min \left(V_{1}, V_{2}, V_{3}\right)
$$

Denklemde " $V_{1}$ " cer kuvveti, çekilecek yük ve trene etki eden direnç kuvvetlerinin bilindiği durumda lokomotifin çekebileceği yüke göre yapılabileceği hız, " $V_{2}$ " trenin kurpdaki hız sınırı, " $V_{3}$ " trenin acil durumda fren mesafesinin sağlanması için izin verilen en yüksek hızdır. $V_{1}$ hızı hesaplanırken öncelikle aday bir hız kabul edilir ve trene etki eden birim direnç kuvvetleri hesaplanarak lokomotif cer kuvveti ile eşitleme yapılır. Cer kuvvetlerinin eşit olmamas1 durumunda farklı bir aday hızı seçilir. Bu işlem Microsoft Excel yazılımı "Hedef Ara" fonksiyonu aracılığıyla her demiryolu kesiti için uygulanmıştır. Çalışmada trenlerin sefer süreleri mikrosimülasyon modeli ile hesaplanacak, bu sayede demiryolu kesitlerinde trenlerin hizlanma ve frenleme sürelerini etkileyen ivmelerin toplam sefer süresine etkisi dikkate alınacaktır. Tipik bir yük treninin güzergah boyunca hız değişimleri Şekil 2'de gösterilmiştir. 


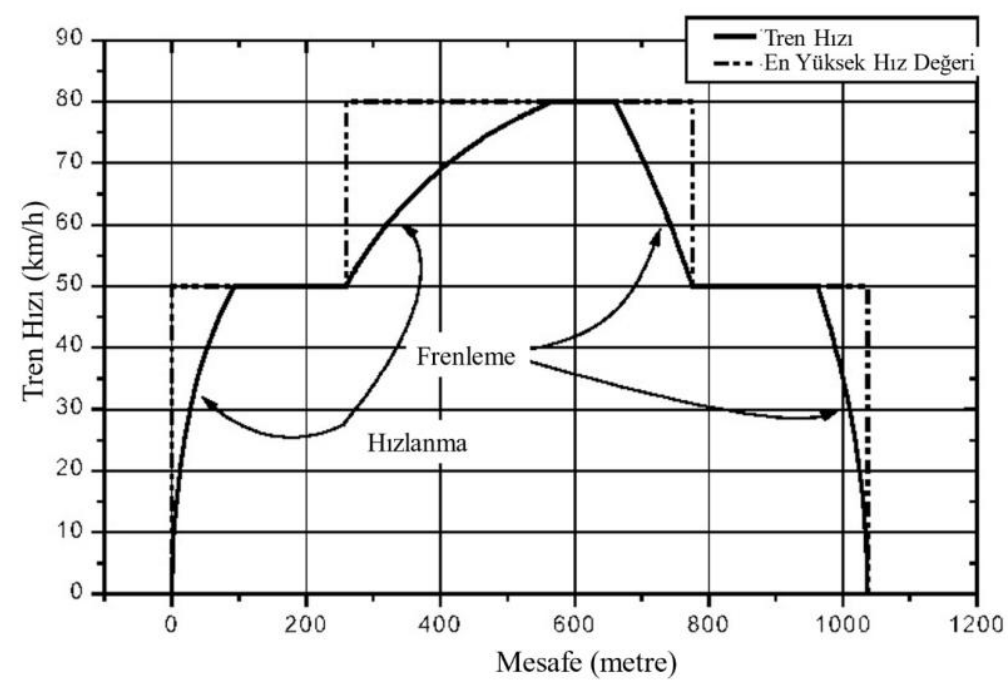

Şekil 2. Tipik bir yük treninin güzergah boyunca hız değişimleri [27]

\subsection{Simülasyon modelinin hazırlanmast ve işletimi}

Çalışmada ilk olarak liman ile yük istasyonu arasındaki demiryolu hattının karakteristik özellikleri incelenmiştir. Demiryolu kesitlerindeki yatay ve düşey kurpların belirlenmesi için yüksek çözünürlüklü dijital yükseklik haritası ile Google Maps Pro yazılımı kullanılmıştır. Liman ve yük istasyonu arasındaki demiryolu hattında yatay kurplar ve aliymanların başlangıç, bitiş ve some noktaları belirlenmiştir. Yazılım vasıtası ile güzergah boyunca rampa başlangıç ve bitiş kotları çıkartılarak kesitlerdeki ortalama rampa eğimleri hesaplanmıştır. Güzergah üzerindeki kurplar ve yarıçapları Şekil 4, Şekil 5 ve Şekil 5'de görülmektedir.

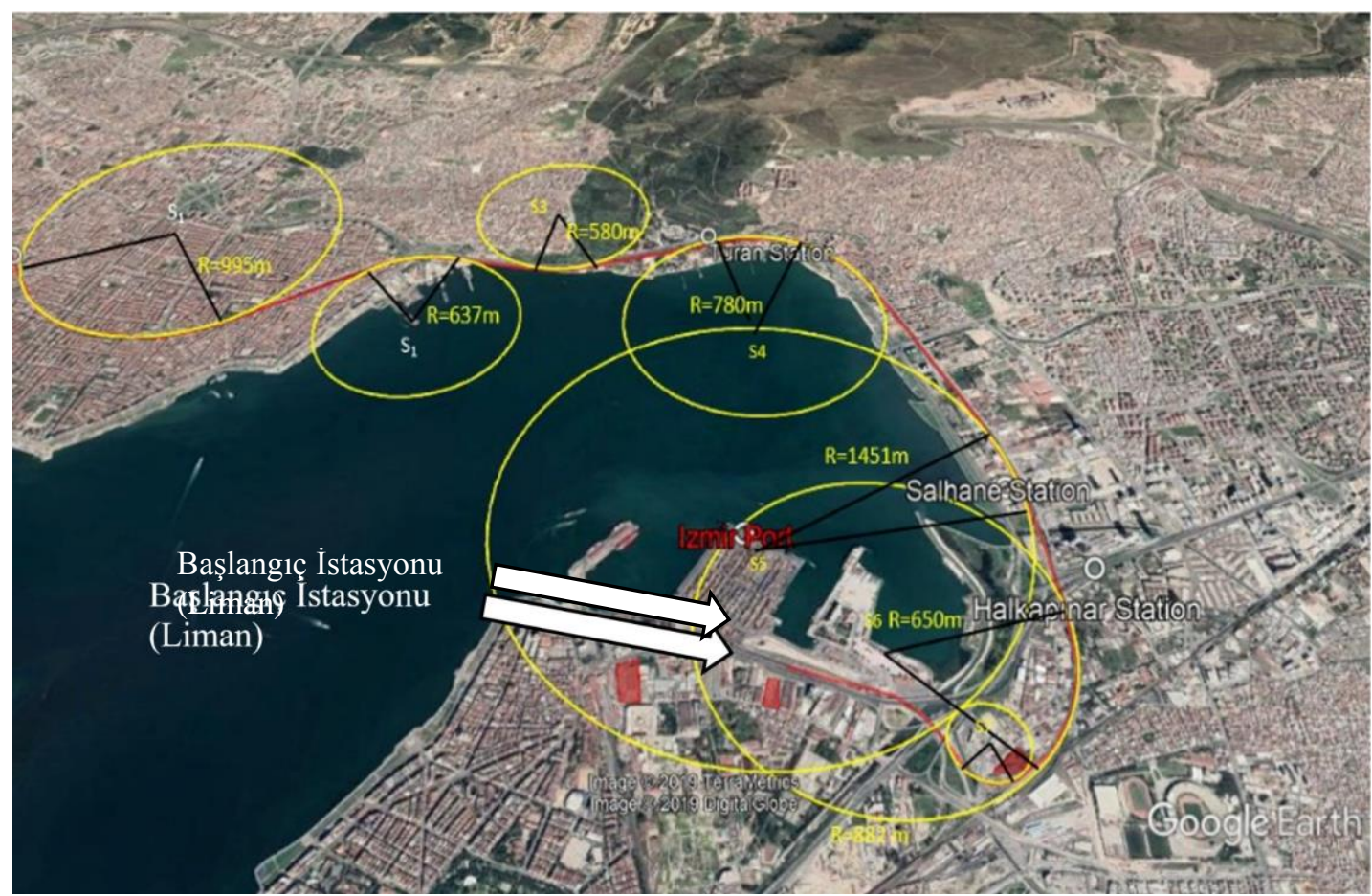

Şekil 3. Halkapınar ile Karşıyaka istasyonları arası hat için kurp özellikleri [28] 


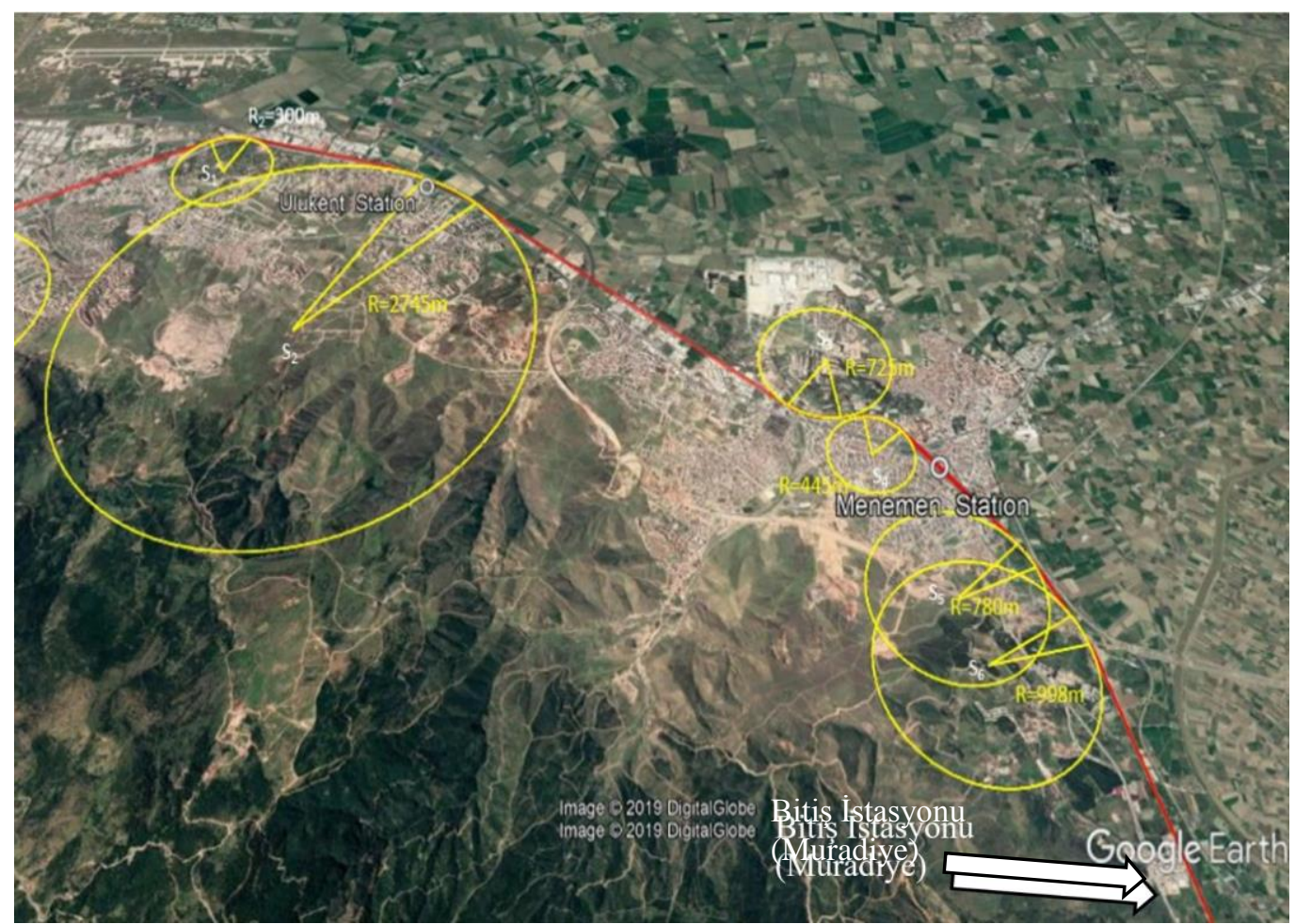

Şekil 4. Çiğli ile Menemen istasyonları arası hat için kurp özellikleri [28]

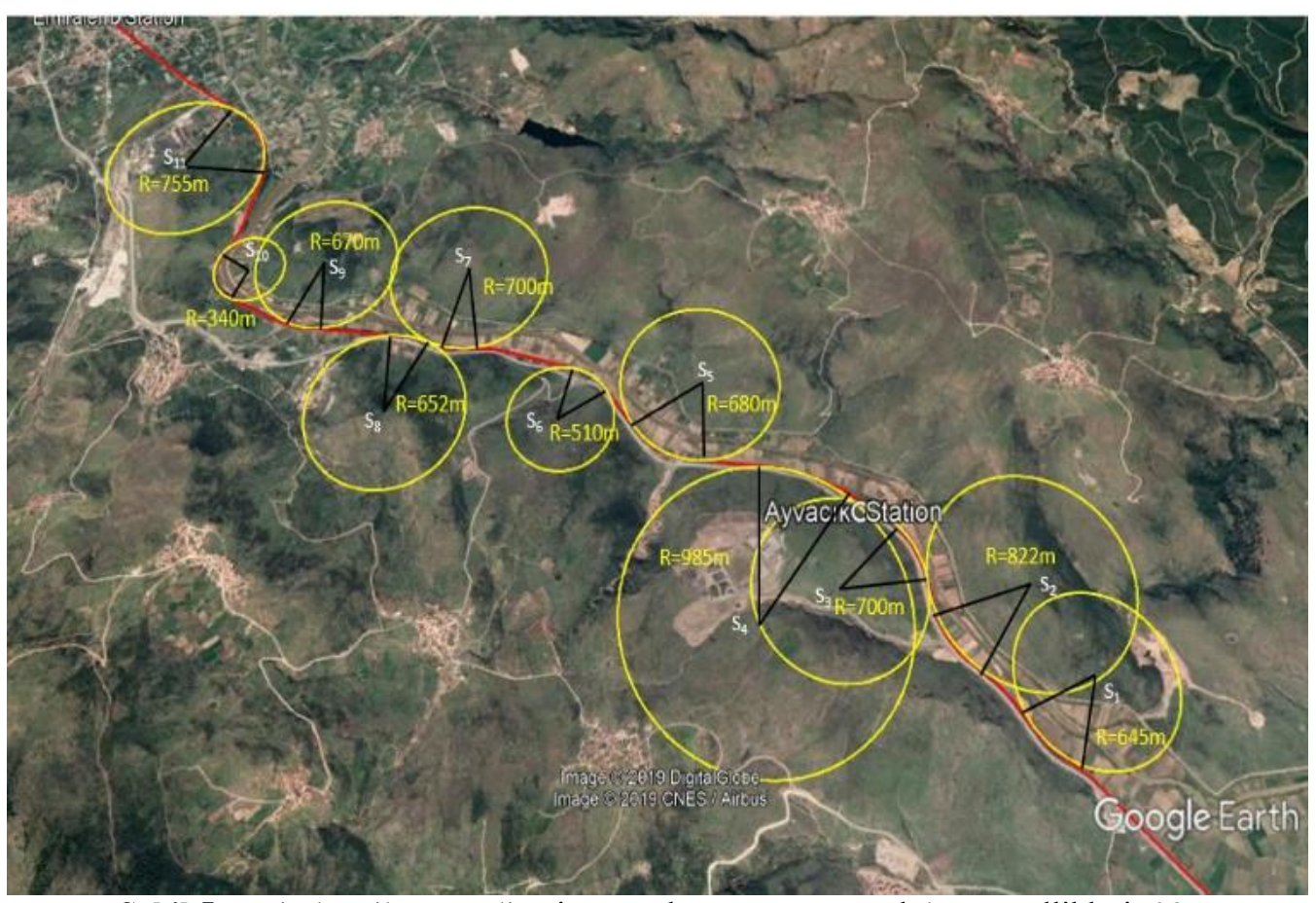

Şekil 5. Emiralem ile Muradiye istasyonları arası güzergah kurp özellikleri [28]

Çalışmada demiryolu güzergahında bulunan istasyonlar, istasyon kilometreleri, sayding uzunlukları belirlenmiştir. İstasyon sayding sayıları ve boyları Tablo 1'de gösterilmiştir. 
Tablo 1. Güzergah üzerindeki istasyonlar ve sayding uzunlukları

\begin{tabular}{ccccc}
\hline İstasyon Adı & SD 1 $(\mathrm{m})$ & SD 2 $(\mathrm{m})$ & SD 3 $(\mathrm{m})$ & SD $4(\mathrm{~m})$ \\
\hline Halkapınar & 650 & 650 & 561 & 624 \\
Salhane & 618 & 548 & Yok & Yok \\
Turan & 809 & 719 & 719 & Yok \\
Karşıyaka & 691 & 559 & 560 & Yok \\
Çiğli & 659 & 704 & 729 & 726 \\
Ulukent & 817 & 594 & 528 & Yok \\
Menemen & 1046 & 541 & 966 & 870 \\
Emiralem & 363 & 793 & 793 & Yok \\
Ayvacık & 421 & 621 & 622 & Yok \\
Muradiye & 1186 & 1175 & 1040 & Yok \\
\hline
\end{tabular}

SD X: "X" nolu sayding

Güzergah araştırması sonucunda kurplar belirlendikten sonra, demiryolu, farklı aliyman eğimleri için kesitlere ayrılmıştır. Liman yönünde demiryolu hattında kot değişimlerinin bulunduğu kesitler belirlenerek bu kesitler için kot okumaları dijital yükseklik haritası üzerinden yapılmıştır. İlk ve son istasyonlar arası 17 demiryolu kesitine bölünerek her kesit için eğim değerleri ve kesit içerisinde kalan minimum yarıçaplı kurpların yarıçap değerleri hesaplanmıştır. Kesitler için en küçük kurp yarıçap1, eğim ve kot değerleri Tablo 2'de gösterilmiştir.

Tablo 2. Demiryolu kesitleri için kot, eğim ve kurp karakteristikleri

\begin{tabular}{cccccc}
\hline Istasyon & Kesit & KM & Kot $(\mathrm{m})$ & Eğim $(\%)$ & $\mathrm{R}_{\mathrm{m}}(\mathrm{m})$ \\
\hline \multirow{2}{*}{ HP } & 1 & 0 & 32 & - & - \\
& 2 & $2+120$ & 22 & -4 & 680 \\
& 3 & $4+339$ & 20 & -1 & 700 \\
Turan & 4 & $6+449$ & 28 & 4 & 0 \\
Salhane & 5 & $8+558$ & 24 & -2 & 750 \\
& 6 & $10+800$ & 22 & -1 & 800 \\
Çiğli & 7 & $13+300$ & 31 & 4 & 695 \\
& 8 & $16+500$ & 18 & -4 & 650 \\
Ulukent & 9 & $18+100$ & 21 & 2 & 750 \\
Menemen & 10 & $23+700$ & 11 & -4 & 0 \\
Emiralem & 11 & $28+000$ & 19 & 3 & 0 \\
& 12 & $34+900$ & 6 & -3 & 445 \\
& 13 & $37+900$ & 4 & 0 & 630 \\
Ayvack & 14 & $40+200$ & 9 & 2 & 1200 \\
Muradiye & 15 & $43+600$ & 1 & -3 & 1250 \\
K & 16 & $48+740$ & 9 & 2 & 995 \\
\hline
\end{tabular}

*KM: kesit kilometresi

Eğimler liman ve kuru liman yönüne birbirlerinin ters işaretleri olarak alınmaktadırlar. Belirlenen demiryolu kesitleri için trenlerin seyir hızları çeker hesapları ile hesaplanmıştır. Belirtilen denklemler ile tren hareketindeki hızlanma ve yavaşlanma kesitleri analitik olarak hesaplanabilmekle beraber, trenin hareketinin ayrıntılı olarak belirlenmesi için bir mikrosimülasyon modeli kullanılacaktır. Çalışmada vagon başına ortalama ağırlık $G_{V}=35,5$ ton kabul edilmiştir. Demiryolu kesitleri için işletme hızları Microsoft Excel yazılımı Hedef Ara fonksiyonu yardımı ile belirlenmiştir. Bu aşamada öncelikle belirlenen aday tren hızı için lokomotif ve vagon dirençleri, kurp ve dever durumlarına göre hesaplanarak toplam direnç ve lokomotif cer kuvveti ile eşitlenmiştir. Demiryolu kesitlerindeki işletme hızları belirlendikten sonra, sefer sürelerinin belirlenmesi için etmen tabanlı AnyLogic simülasyon programı ile özgün Java program kodu 
yazılarak bir mikro-simülasyon modeli hazırlanmıştır. Demiryolu kesitlerindeki tren hareketleri, her bir kesiti temsil eden model blokları kullanılarak hat boyunca modellenmiştir. Tren hareketlerinin simülasyonu için kullanılan model blokları Şekil 6'de görülmektedir.

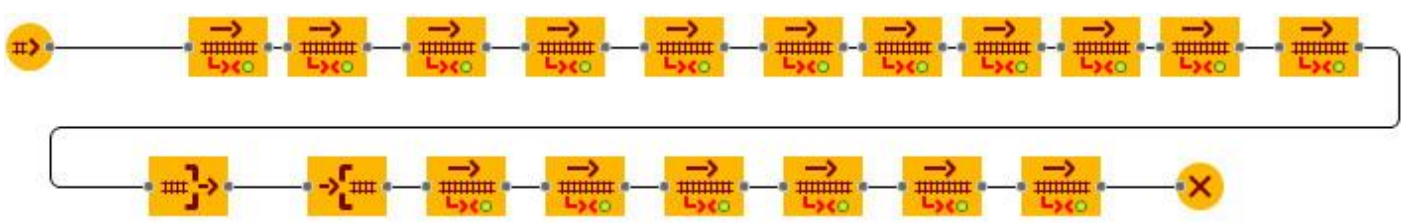

Şekil 6. Tren hareketlerinin simülasyonu için kullanılan model blokları

Simülasyon modeli ile demiryolu kesitleri için, işletme hızları kullanılarak toplam sefer süresi her iki yön için belirlenmiştir. Modelleme aşamasında sistemin simülasyon ortamına aktarılmasında bir takım kabullerde bulunulmuştur. Özellikle demiryolu hattını paylaşan yolcu trenleri nedeniyle mekik trenlerin gün içindeki sefer planlaması sofistike bir simülasyon yazılımı ile yapılabilmektedir. Bu aşamadaki en önemli kabul, mekik tren operasyon saatlerinde hat üzerinde sadece mekik trenlerin işletilmesidir. Bu kabul ile yük trenleri ve yolcu trenleri arasındaki karmaşık etkileşim ve hat kaynaklarının kullanılmasındaki hiyerarşik kurallar modelleme kapsamından çıkarılmıştır ve karmaşık modelleme yaklaşımlarının önüne geçilmiştir. Mekik tren işletmeciliğinin yapılacağı saatler, hattı kullanan mevcut tarifeli trenlerinin olmadığı gece saatlerinde yapılması planlanmıştır. Çalışmada kullanılan AnyLogic demiryolu kütüphanesindeki model blok şekilleri, isimleri ve blok açıklamaları Tablo 3'de gösterilmiştir.

Tablo 3. AnyLogic programında kullanılan simülasyon blokları

\begin{tabular}{|c|c|c|}
\hline Blok şekli & Blok ismi & Açıklama \\
\hline & "Train Source" & $\begin{array}{c}\text { Kuru liman yönünde seçili lokomotif ve vagon sayısı için } \\
\text { tren seferini başlatır }\end{array}$ \\
\hline & "Train Move To" & Trenin kesitler arasında limit hızlar ile hareketini sağlar \\
\hline & "Train Enter" & $\begin{array}{c}\text { Tren varlığını yük boşaltma ve doldurma operasyonu için } \\
\text { hat dışına alır }\end{array}$ \\
\hline & "Train Exit" & Treni ters yönde yapılacak sefer için hatta alır \\
\hline & "Train Dispose" & $\begin{array}{l}\text { Tren varlığını sistemden çıkarır ve sefer istatistiklerini } \\
\text { kaydeder }\end{array}$ \\
\hline & "Resource Pool" & Demiryolu kesitlerindeki kaynakları simüle eder. \\
\hline$\pi_{0}$ & "Seize" & Kesitler için kaynaklara el koyar \\
\hline - & "Release" & Kaynakları bırakır \\
\hline
\end{tabular}

Çalışmada trenler üretildikten sonra demiryolu hatına alınarak, bu hatları temsil eden model kaynaklarını kendisine ayırmak için talepte bulunmakta, kaynağın kendi için ayrılmasından sonra bu hat kesiminde ilerlemekte, hareketin sonunda gelecek kaynak için talepte bulunmaktadır. Eğer bir sonraki kaynak başka bir tren tarafından işgal ediliyorsa hat sonunda beklemekte ve mevcut hat kaynağını işgal etmektedir. Tren sefer saatleri boyunca hattın bakım ve onarım gibi faaliyetler nedeniyle hat işletmeciliği kesintiye uğramayacağı kabul edilmiştir. Liman ve kuru liman arasında gidiş ve geliş olmak üzere çift yönlü demiryolu hattı olduğu kabul edilmiştir. Çalışmada TCDD tarafından kullanılmakta olan 3300 beygir gücündeki DE33000 $2463 \mathrm{~kW}$ dizel elektrikli lokomotifi ve E68000 5000kW gücündeki elektrikli Hyundai Rotem lokomotifleri kullanılacaktır. [29]. Bu lokomotifler halihazırda yük taşımacılığı için TCDD tarafından yoğun şekilde kullanılmaktadır. Çalışmada kullanılan lokomotifler Şekil 7'da görülmektedir. 

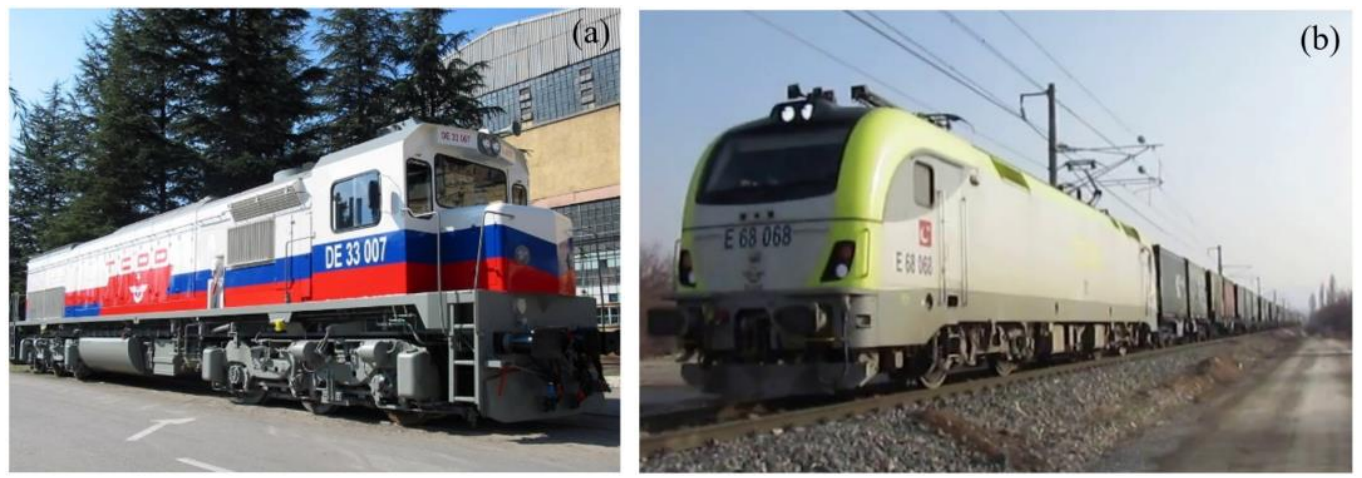

Şekil 7. (a) DE33000 ve (b) E68000 tip lokomotifler [29]

Lokomotifler ağırlıkları ve dingil sayıları DE33000 için 120 ton ve 6 dingil, ve E68000 için 90 ton ve 4 dingil olarak kabul edilmiştir. Lokomotifler için $A_{L}$ değeri $12 \mathrm{~m}^{2}$ ve maksimum hız 130 $\mathrm{km} / \mathrm{h}$ olarak kabul edilmiştir.

\subsection{Mikro-simülasyon modelinin doğrulanması}

Simülasyon modelinin doğrulanması aşamasında $0.5 \mathrm{~m} / \mathrm{s}^{2}$ tren ivme değeri girilerek simülasyon çalıştırılmıştır. Simülasyon yaklaşımının etkinliğinin gösterilmesi amacıyla model ayrıca çok yüksek bir ivme değeri ile çalıştırılmış ve her iki model koşumu için hız-zaman ve hız-yol grafikleri elde edilmiştir. Yüksek ivme değeri ve $0.5 \mathrm{~m} / \mathrm{s}^{2}$ ivme değeri için hız-zaman ve yolzaman grafikleri Şekil 8 ve Şekil 9'de görülmektedir.
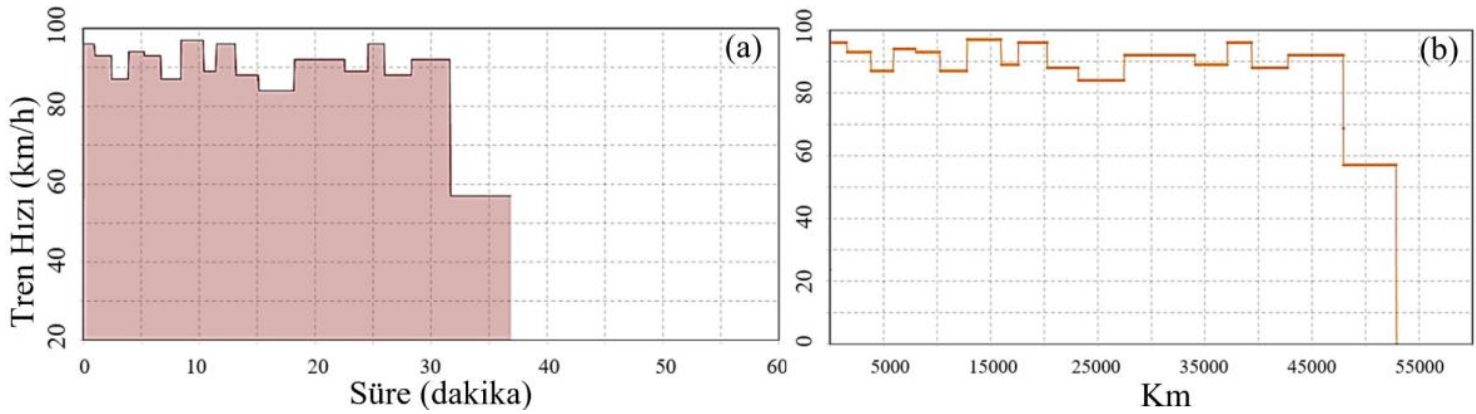

Şekil 8. Yüksek ivme değeri için (a) hız-zaman (b) hız-yol grafiği
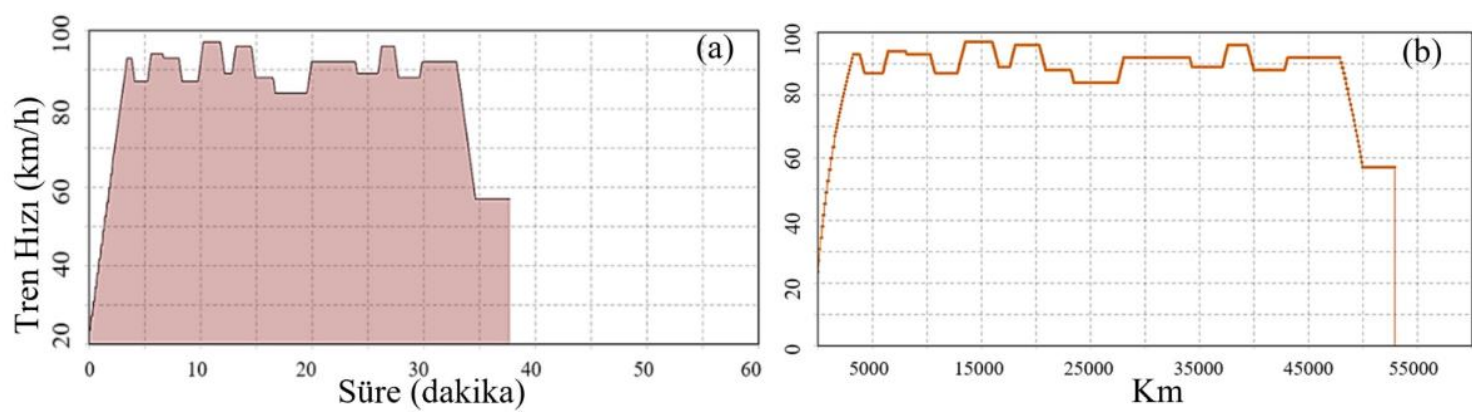

Şekil 9. $0,1 \mathrm{~m} / \mathrm{s}^{2}$ ivmesi için (a) hız-zaman (b) hız-yol grafiğgi

Simülasyon modelinin doğrulanma aşamasında $0.5 \mathrm{~m} / \mathrm{s}^{2}$ ivme değeri ile hareket eden trenin kesitlerde izin verilen hızlara daha uzun sürelerde ulaşabildiği görülmektedir. 


\section{Bulgular}

DE33000 ve E68000 lokomotifi kullanılarak 40 vagon çekiminde 1000 metrelik fren mesafesi için liman yönünde hesaplanan maksimum kesit hızları Tablo 4 ve Tablo 5'de gösterilmiştir.

Tablo 4. DE33000 $\mathrm{S}=1000 \mathrm{~m} N_{V}=40$ parametreleri için kesit hızları $(\mathrm{km} / \mathrm{h})$

\begin{tabular}{|c|c|c|c|c|c|c|c|c|c|c|}
\hline \multirow[b]{2}{*}{ İstasyon } & \multirow[b]{2}{*}{ KM } & \multirow[b]{2}{*}{ Kot (m) } & \multirow[b]{2}{*}{ Eğim } & \multirow[b]{2}{*}{$\mathrm{Rm}$} & \multicolumn{3}{|c|}{ Aktarma istasyonu yönü } & \multicolumn{3}{|c|}{ Liman yönü } \\
\hline & & & & & V1 & $\mathrm{V} 2$ & V3 & V1 & $\mathrm{V} 2$ & V3 \\
\hline \multirow[t]{3}{*}{$\mathrm{HP}$} & $2+120$ & 22 & $-0,004$ & 680 & 105 & 104 & 96 & 64 & 104 & 87 \\
\hline & $4+339$ & 20 & $-0,001$ & 700 & 89 & 106 & 93 & 79 & 106 & 90 \\
\hline & $6+449$ & 28 & 0,004 & & 69 & & 87 & 112 & & 96 \\
\hline Turan & $8+558$ & 24 & $-0,002$ & 750 & 95 & 110 & 94 & 74 & 110 & 89 \\
\hline \multirow[t]{3}{*}{ Salhane } & $10+800$ & 22 & $-0,001$ & 800 & 90 & 113 & 93 & 80 & 113 & 90 \\
\hline & $13+300$ & 31 & 0,004 & 695 & 65 & 105 & 87 & 105 & 105 & 96 \\
\hline & $16+500$ & 18 & $-0,004$ & 650 & 107 & 102 & 97 & 63 & 102 & 86 \\
\hline \multirow[t]{2}{*}{ Çiğli } & $18+100$ & 21 & 0,002 & 750 & 74 & 110 & 89 & 95 & 110 & 94 \\
\hline & $20+800$ & 11 & $-0,004$ & & 111 & & 96 & 69 & & 87 \\
\hline Ulukent & $23+700$ & 19 & 0,003 & & 74 & & 88 & 106 & & 95 \\
\hline Menemen & $28+000$ & 6 & $-0,003$ & 445 & 98 & 84 & 95 & 65 & 84 & 88 \\
\hline \multirow[t]{4}{*}{ Emiralem } & $34+900$ & 4 & 0,000 & 630 & 85 & 100 & 92 & 82 & 100 & 91 \\
\hline & $37+900$ & 9 & 0,002 & 1200 & 77 & 139 & 89 & 96 & 139 & 94 \\
\hline & $40+200$ & 1 & $-0,003$ & 1250 & 107 & 141 & 96 & 68 & 141 & 87 \\
\hline & $43+600$ & 9 & 0,002 & 995 & 73 & 126 & 88 & 99 & 126 & 94 \\
\hline Ayvacık & $48+740$ & 6 & $-0,001$ & 580 & 86 & 96 & 92 & 79 & 96 & 91 \\
\hline Muradiye & $53+700$ & 1 & $-0,001$ & 200 & 71 & 57 & 93 & 61 & 57 & 90 \\
\hline
\end{tabular}

Tablo 5. E68000 S=1000m $N_{V}=40$ parametreleri için kesit hızları $(\mathrm{km} / \mathrm{h})$

\begin{tabular}{ccccccccccc}
\hline & & & \multicolumn{3}{c}{ Kuru liman yönü } & \multicolumn{5}{c}{ Liman yönü } \\
& $\mathrm{KM}$ & $\mathrm{Kot}(\mathrm{m})$ & $\mathrm{Eğim}$ & $\mathrm{R}_{\mathrm{m}}$ & $\mathrm{V}_{1}$ & $\mathrm{~V}_{2}$ & $\mathrm{~V}_{3}$ & $\mathrm{~V}_{1}$ & $\mathrm{~V}_{2}$ & $\mathrm{~V}_{3}$ \\
\hline HP & $2+120$ & 22 & $-0,004$ & 680 & 131 & 104 & 96 & 97 & 104 & 87 \\
& $4+339$ & 20 & $-0,001$ & 700 & 118 & 106 & 93 & 110 & 106 & 90 \\
& $6+449$ & 28 & 0,004 & & 101 & & 87 & 136 & & 96 \\
Turan & $8+558$ & 24 & $-0,002$ & 750 & 123 & 110 & 94 & 105 & 110 & 89 \\
Salhane & $10+800$ & 22 & $-0,001$ & 800 & 118 & 113 & 93 & 110 & 113 & 90 \\
& $13+300$ & 31 & 0,004 & 695 & 98 & 105 & 87 & 130 & 105 & 96 \\
& $16+500$ & 18 & $-0,004$ & 650 & 132 & 102 & 97 & 95 & 102 & 86 \\
Çiğli & $18+100$ & 21 & 0,002 & 750 & 106 & 110 & 89 & 123 & 110 & 94 \\
& $20+800$ & 11 & $-0,004$ & & 135 & & 96 & 102 & & 87 \\
Ulukent & $23+700$ & 19 & 0,003 & & 106 & & 88 & 131 & & 95 \\
Menemen & $28+000$ & 6 & $-0,003$ & 445 & 125 & 84 & 95 & 97 & 84 & 88 \\
Emiralem & $34+900$ & 4 & 0,000 & 630 & 114 & 100 & 92 & 112 & 100 & 91 \\
& $37+900$ & 9 & 0,002 & 1200 & 108 & 139 & 89 & 123 & 139 & 94 \\
& $40+200$ & 1 & $-0,003$ & 1250 & 132 & 141 & 96 & 100 & 141 & 87 \\
Ayvac1k & $43+600$ & 9 & 0,002 & 995 & 104 & 126 & 88 & 126 & 126 & 94 \\
Muradiye & $48+740$ & 6 & $-0,001$ & 580 & 115 & 96 & 92 & 110 & 96 & 91 \\
\hline
\end{tabular}

Özellikle liman ve aktarma istasyonu arasındaki kot farkı ve ortalama eğim sebebiyle lokomotif çeki hesapları ve frenleme mesafesi denklemleri ile elde edilen maksimum kesit hızları arasında farklılıklar görülmüştür. Tablolarda $R_{m}$ kesitdeki en küçük kurp yarı çapıdır. Hesaplanan her iki tablo için, kuru liman yönüne yapılacak seferlerde kesit eğimleri negatif değerleri alınmıştır. Tren fren kuvvetleri ve güzergah geometrileri dikkate alındığında E68000 ve DE33000 lokomotifleri için liman ve kuru liman yönünde ortalama $\mathrm{V}_{2}$ değerinin benzer olduğu görülmektedir. Tablolar incelendiğinde ise $\mathrm{V}_{1}$ hızları için her iki lokomotif tipinde farklılıklar görülmekte, bu da lokomotif cer kuvvetinin $\mathrm{V}_{1}$ hızının belirlenmesinde önemli olduğunu ortaya koymaktadır.

Yapılan mikro-simülasyon çalışması sonuçları kullanılarak lokomotif tipleri için farklı vagon sayıları ve sefer yönlerine göre çeker hesapları yapılmış ve tren sefer süreleri hesaplanmıştır. 
Mekik trenlerde her bir sefer döngüsü için ise 20 dakikalık bir son istasyon bekleme süresi $\left(T_{s}\right)$ kabul edilmiştir. Liman ve kuru liman yönleri için farklı vagon sayıları $\left(\mathrm{N}_{\mathrm{V}}\right)$ ve farklı lokomotif tiplerine göre sefer süreleri Tablo 6'da gösterilmiştir.

Tablo 6. Vagon sayısı ve lokomotif tiplerine göre sefer süreleri

\begin{tabular}{|l|c|c|c|c|}
\hline Parametreler & DE33000 (Dizel elektrikli) & \multicolumn{2}{c|}{ E68000 (Elektrikli) } \\
\hline$N_{V}$ & 30 & 40 & 30 & 40 \\
\hline Liman yönü sefer süresi (dak) & $36.2(35,1)^{*}$ & $39,1(41,7)$ & $31.2(39,7)$ & $32.4(38,9)$ \\
\hline Kuru liman yönü sefer süresi (dak) & $39.8(38,8)$ & $45,6(44,1)$ & $35.0(39,5)$ & $35.8(39,8)$ \\
\hline$T_{\mathrm{s}}$ (dakika) & \multicolumn{4}{|c|}{20} \\
\hline$T_{\text {tot }}$ (dakika) & $95.8(100,3)$ & $104,6(105,4)$ & $87,2(99,2)$ & $88.2(98,8)$ \\
\hline
\end{tabular}

*mikro-simülasyon modelinin kullanılmadığı durumlarda hesaplanan sefer süreleri, $\mathrm{T}_{\text {tot }}$ : Toplam sefer döngü süresi

Sonuçlar değerlendirildiğinde, her iki lokomotifin de kuru liman yönündeki sefer sürelerinin daha uzun olduğu görülmüştür. Yönler arasındaki süre farkı dizel-elektrikli DE33000 lokomotifi için 30 vagonda çekimi durumunda $\% 1,7$ ve 40 vagon çekimi durumunda $\% 4,5$ olarak hesaplanmıştır. Aynı zamanda sefer süreleri arasındaki fark E68000 lokomotifinin kullanıldığı 30 ve 40 vagon çekim senaryolarında $\% 0,7$ ve $\% 1,2$ olduğu görülmüştür.

Lokomotiflerin cer kuvvetleri farklı1ığından doğan taşımacılık kapasitesi fark1 incelendiğinde E68000 lokomotifinin DE33000 lokomotifine oranla günlük 30 ve 40 vagonlu katarlar için \%1,1 ve \%5,9 daha kısa sürede sefer döngüsünü tamamladığı görülmektedir. Hattın TEU taşıma kapasitesinin incelenmesi için 3 TEU kapasiteli Türasaş 18.5 metrelik konteyner platform vagonları kullanımı senaryosu kabul edilmiştir [30]. Hat üzerinde çalıştıılan yük treni sayısı ile günlük taşımacılık kapasitesinin incelenmesi için farklı lokomotif sayıları ile model 8 saatlik işletme periyodu kabulü ile çalıştırılmış ve trenlerin ortalama sefer süreleri, tamamladıkları toplam sefer sayısı ve TEU cinsinden taşımacılık kapasitesi belirlenmiştir. Farklı sayıda lokomotif kullanım senaryoları için 8 saatlik işletim senaryosunda hat kapasiteleri ve sefer gecikmeleri Tablo 7'de gösterilmiştir.

Tablo 7. Farklı sayıda lokomotif işletimi durumunda ortalama sefer süresi ve sefer sayısı

\begin{tabular}{ccccccc}
\hline Lokomotif & \multicolumn{3}{c}{ DE33000 (dizel elektrik) } & \multicolumn{3}{c}{ E68000 (Elektrik) } \\
Say1s1 & $\mathrm{N}_{\mathrm{s}}$ & $\mathrm{TEU}$ & $\mathrm{D}_{\mathrm{t}}$ (dak.) & $\mathrm{N}_{\mathrm{s}}$ & $\mathrm{TEU}$ & $\mathrm{D}_{\mathrm{t}}($ dak.) \\
\hline $2-2$ & 16 & 1920 & 104.6 & 17 & 2040 & 88.2 \\
$4-4$ & 30 & 3600 & 105.9 & 33 & 3960 & 89.4 \\
$6-6$ & 42 & 5040 & 107.3 & 46 & 5520 & 90.7 \\
$8-8$ & 54 & 6480 & 108.8 & 59 & 7080 & 92.1 \\
$10-10$ & 66 & 7920 & 110.2 & 73 & 8760 & 93.5 \\
$12-12$ & 73 & 8760 & 116.3 & 82 & 9840 & 99.2 \\
$14-14$ & 75 & 9000 & 136.6 & 85 & 10200 & 118.3 \\
$16-16$ & 77 & 9240 & 158.1 & 86 & 10320 & 138.5 \\
$18-18$ & 78 & 9360 & 177.8 & 86 & 10320 & 157.1 \\
$20-20$ & 78 & 9360 & 197.2 & 86 & 10320 & 175.1 \\
$22-22$ & 78 & 9360 & 215.7 & 86 & 10320 & 192.7 \\
\hline
\end{tabular}

$\mathrm{N}_{\mathrm{s}}$ : Sefer sayısı, TEU: Taşımacılık kapasitesi (TEU), $\mathrm{D}_{\mathrm{t}}$ : Ortalama sefer süresi

Simülasyon modeli sonucunda sadece mekik trenlerin çalıştırılacağ 8 saatlik işletme süresinde toplam 4 lokomotifin işletildiği (2-2) senaryosu için, E68000 lokomotiflerinin DE33000 lokomotiflerine oranla \%6.25 daha fazla TEU taşıyabildiği ortaya konmuştur. (2-2) senaryosu dışında işletilen lokomotif sayısı arttıkça her iki senaryo için trenler blokajı ve dolayısıyla gecikmeler ortaya çıkmaktadır. Bu noktada E68000 lokomotifinin elektrikli lokomotif olması nedeni ile dizel elektrik muadiline oranla çevresel ve ekonomik anlamda avantajları olduğuna da dikkat çekilmelidir. 


\section{Sonuç}

Bu çalışmada mekik trenler için ayrılmış veya sadece mekik tren operasyonlarının yapılabileceği işletme saatler için yük taşımacıllğı kapasitesinin belirlenebileceği bir mikro-simülasyon destekli analiz yöntemi geliştirilmiştir. Bu yöntem ile lokomotif çeker denklemleri ve hat geometrisi, farklı lokomotif tipleri ve vagon sayıları için sefer süreleri belirlenerek hat kapasitesi belirlenmiştir. Çalışmanın literatüre diğer bir katkısı ise, kesikli olay simülasyon yöntemleri kullanılarak mekik trenler için yük taşımacılığı kapasite hesabının yapılabileceği ve mikrosimülasyon ve tren hareket denklemleri ile daha tutarlı tren sefer sürelerinin hesaplanabileceğinin gösterilmesi olmuştur. Sonuçlarda görülmektedir ki:

- Elektrikli (E68000) lokomotif, dizel elektrikli (DE33000) lokomotifine oranla daha hizlı ve yüksek kapasiteli bir demiryolu taşımacılığı sağlamakta, elektrikli lokomotif kullanımı sayesinde ekonomik ve çevresel faydalar sağlanabilmektedir.

- Hattın tarifeli trenler veya yolcu trenleri tarafından kullanılmadığı 8 saatlik işletim periyodunda, elektrikli tren, dizel elektrikli trene oranla daha fazla yük taşıyabilmektedir. $\mathrm{Bu}$ kısıtlı zaman periyodunda en yüksek taşımacılık kapasitesine erişebilmek için elektrikli tren kullanımı daha uygun bulunmuştur. 8 saatlik (2-2) lokomotif işletme senaryosunda elektrikli lokomotif için \%6.25 daha fazla taşıma kapasitesi hesaplanmıştır. Lokomotif sayısının iki ve daha fazla katına çıkarıldığ 1 senaryolarda ise her iki lokomotif tipi için sefer süreleri hat sıkışıklığı nedeniyle uzamaktadır.

- Her iki lokomotif için kuru liman yönündeki sefer sürelerinin, liman yönüne oranla daha uzun gerçekleştirildiği görülmüştür. Bu noktada daha yüksek cer kuvvetine sahip olan E68000 lokomotifi DE33000 lokomotifine oranla kot farkından daha az etkilenmektedir. Bu farkın sebebi özellikle katar çeki denklemlerinin etkili olduğu kurpsuz aliyman kesitlerindeki çeki hızları arasındaki farktır.

- Yönler arasındaki süre farkı dizel-elektrikli DE33000 lokomotifi için 30 vagonda çekimi durumunda $\% 1,7$ ve 40 vagon çekimi durumunda \%4,5 olarak hesaplanmıştır. Aynı zamanda sefer süreleri arasındaki fark E68000 lokomotifinin kullanıldığ 130 ve 40 vagon çekim senaryolarında $\% 0,7$ ve $\% 1,2$ olduğu görülmüştür.

- Çalışmada kullanılan mikro-simülasyon yöntemi ile trenlerin demiryolu kesitleri arasındaki hareketlerinin tren hızlanma ve frenleme ivmelerinin kullanılması ile birlikte daha gerçekçi modellenebildiği görülmektedir. Çalışmada matematiksel hareket denklemleri ile mikrosimülasyon modellerinin beraber kullanımının sefer süresi ve hat taşımacılık kapasitesinin hesaplanmasında daha gerçekçi sonuçlar verdiği gösterilmiştir.

Bu çalışmanın devamında, elektrikli ve dizel lokomotiflerinin liman ve kuru liman arasındaki yük taşımacılığının ekonomik analizi, elektrifikasyon yatırımlanı ve trenlerin kilometre başına taşımacılık maliyetlerinin etkileri çalışılması planlanan araştırma konularıdır. 


\section{Kaynakça}

[1] A. Carboni ve F. Orsini, "Dry ports and related environmental benefits: a case study in Italy," Case Studies on Transport Policy, vol. 8, no. 2, pp. 416-428, Jun. 2020, doi: 10.1016/j.cstp.2020.05.009.

[2] M. S. Yıldırım, M. Karaşahin, ve Ü. Gökkuş, "Scheduling of the shuttle freight train services for dry ports using multimethod simulation-optimization approach," Int J Civ Eng, Aug. 2020, doi: 10.1007/s40999-020-00553-0.

[3] R. Elbert ve D. Reinhardt, "Increasing capacity utilization of shuttle trains in intermodal transport by investing in transshipment technologies for non-cranable semi-trailers," in 2016 Winter Simulation Conference (WSC), Washington, DC, USA, Dec. 2016, pp. 2358-2369. doi: 10.1109/WSC.2016.7822276.

[4] Y. Chen ve H. Shi, "Capacity analysis of rail container freight shuttle train," p. 109.

[5] "UIC leaflet 406, Capacity," UIC International Union of Railways, France, 2, 2013.

[6] TCRP, "Transit Capacity and Quality of Service Manual, 2nd Edition | Blurbs New | Blurbs | Publications," Transport Research Board, 2017. Accessed: Apr. 20, 2021. [Online]. Available: http://www.trb.org/Publications/Blurbs/153590.aspx

[7] H. Pouryousef, P. Lautala, ve T. White, "Railroad capacity tools and methodologies in the U.S. and Europe,” J. Mod. Transport., vol. 23, no. 1, pp. 30-42, Mar. 2015, doi: 10.1007/s40534-015-0069-z.

[8] M. Abril, F. Barber, L. Ingolotti, M. A. Salido, P. Tormos, ve A. Lova, "An assessment of railway capacity," Transportation Research Part E: Logistics and Transportation Review, vol. 44, no. 5, pp. 774-806, Sep. 2008, doi: 10.1016/j.tre.2007.04.001.

[9] S. Binder, Y. Maknoon, ve M. Bierlaire, "The multi-objective railway timetable rescheduling problem," Transportation Research Part C: Emerging Technologies, vol. 78, pp. 78-94, May 2017, doi: 10.1016/j.trc.2017.02.001.

[10] C. Zhang, Y. Gao, L. Yang, U. Kumar, ve Z. Gao, "Integrated optimization of train scheduling and maintenance planning on high-speed railway corridors," Omega, vol. 87, pp. 86-104, Sep. 2019, doi: 10.1016/j.omega.2018.08.005.

[11]“UIC leaflet 406, Capacity,” UIC International Union of Railways, France, 2004.

[12]L. M. Gambardella, A. E. Rizzoli, ve P. Funk, "Agent-based planning and simulation of combined rail/road transport," SIMULATION, vol. 78, no. 5, pp. 293-303, May 2002, doi: 10.1177/0037549702078005551.

[13]Z. Taomei, “An agent-based support system for railway station dispatching," Expert Systems With Applications, p. 14, 2016.

[14] V. Singhania ve M. Marinov, "An event-based simulation model for analysing the utilization levels of a railway line in urban area," PROMET, vol. 29, no. 5, pp. 521-528, Nov. 2017, doi: 10.7307/ptt.v29i5.2306.

[15] A. Lindfeldt, "Railway capacity analysis: methods for simulation and evaluation of timetables, delays and infrastructure," KTH Royal Institute of Technology, Stockholm, 2015.

[16] S. Mu ve M. Dessouky, "Scheduling freight trains traveling on complex networks," Transportation Research Part B: Methodological, vol. 45, no. 7, pp. 1103-1123, Aug. 2011, doi: 10.1016/j.trb.2011.05.021.

[17] H. Pouryousef ve P. Lautala, "Hybrid simulation approach for improving railway capacity and train schedules," Journal of Rail Transport Planning \& Management, vol. 5, no. 4, pp. 211-224, Dec. 2015, doi: 10.1016/j.jrtpm.2015.10.001.

[18]C. Meirich ve N. Nießen, "Calculating the maximal number of additional freight trains in a railway network," Journal of Rail Transport Planning \& Management, vol. 6, no. 3, pp. 200-217, Dec. 2016, doi: 10.1016/j.jrtpm.2016.06.005.

[19] Ö. Yalçınkaya ve G. Mirac Bayhan, "A feasible timetable generator simulation modelling framework for train scheduling problem," Simulation Modelling Practice and Theory, vol. 20, no. 1, pp. 124-141, Jan. 2012, doi: 10.1016/j.simpat.2011.09.005.

[20]Ö. Akbayir, "Demiryolu Araçlarında Enerji Verimliliği ve Tasarrufu,” 2016, p. 10.

[21] M. Ogasa, "Energy saving and environmental measures in railway technologies: example with hybrid electric railway vehicles," IEEJ Transactions on Electrical and Electronic Engineering, vol. 3, no. 1, pp. 15-20, 2008, doi: 10.1002/tee.20227.

[22]H. E. Beni, "Lokomotif çekerleri hesaplama yöntemi," Demiryolu Mühendisliği, Dec. 2020, doi: 10.47072/demiryolu.826780. 
[23] G. Strahl, "Verfahren zur bestimmung der belastungsgrenzen der dampflokomotiven," Z. Des. Vereins Dtsch. Ing, vol. 57, 1913.

[24] Milli Eğitim Bakanlığı, "Raylı sistemler teknolojisi fren dinamiği ve seyir süresi hesabı.” 2013.

[25]Ö. Akbayir ve F. H. Çakir, "Enerji verimliliği için tren direnci formüllerinin karşılaştırılması” p. 15, 2017.

[26] S. Y. Sapronova, V. P. Tkachenko, O. V. Fomin, I. I. Kulbovskiy, e E. P. Zub, "Rail Vehicles: The resistance to the movement and the controllability." 2017.

[27] C. Urlu, Demiryolu araçlarının ileri dinamiği. Ankara: TCDD Yayınları, 1999.

[28] Google Maps, "Google Maps, 2017.," 2017.

[29] TÜLOMSAŞ, “Tülomsaş Ürün Portföyü,” 2019. https://www.tulomsas.com.tr/tulomsas/urunportfoyu/

[30]A. D. R. Ajansı, "Konteyner Vagonu," Türkiye Raylı Sistem Araçları Sanayi A.Ş. https://www.turasas.gov.tr/konteyner-vagonu

\section{Özgeçmiş}

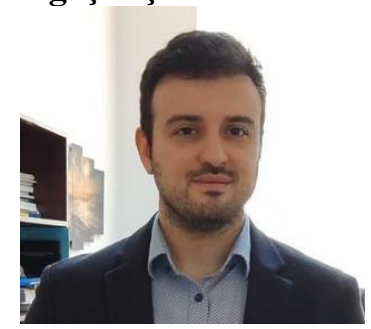

\section{Mehmet Sinan YILDIRIM}

Lisans eğitimini Orta Doğu Teknik Üniversitesinde tamamlamıştır. Manisa Celal Bayar Üniversitesi Mühendislik Fakültesi İnşaat Mühendisliği bölümünde çalışmaktadır. İlgi alanına giren araştırma konuları trafik simülasyonu, demiryolu simülasyonu ve planlaması ve mikro-simülasyon'dur.

E-Posta: msyildirim35@gmail.com

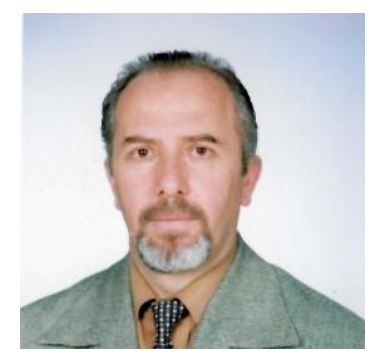

\section{Ümit GÖKKUŞ}

Akdeniz Üniversitesi İnşaat Mühendisliği bölümünü bitirmiştir. Yüksek lisans ve doktora eğitimini Orta Doğu Teknik Üniversitesi ve Dokuz Eylül Üniversitesinde tamamlamıştır. İlgi alanları kıyı yapıları, deniz ve boru hattı ulaştırması ve ulaştırma sanat yapılarıdır. E-Posta: umit.gokkus@cbu.edu.tr

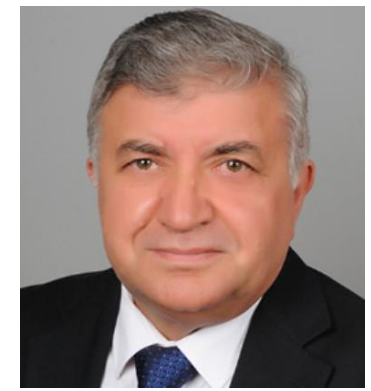

\section{Mustafa KARAŞAHIN}

Akdeniz Üniversitesi İnşaat Mühendisliği bölümünü bitirmiştir. Yüksek Lisans eğitimini İstanbul Teknik Üniversitesi ve Doktora eğitimini The University of Nottingham üniversitelerinde tamamlamıştır. İstanbul Gelişim Üniversitesi İnşaat Mühendisliği bölümünde çalışmaktadır. Çalışma alanları demiryolu mühemdislği, kara yolu üst yapısı ve hava limanları konularıdır E-Posta: mkarasahin@gelisim.edu.tr

\section{Beyanlar:}

Bu makalede bilimsel araştırma ve yayın etiğine uyulmuştur.

Tüm yazarların eşit oranda katkısı olmuştur. 